\title{
Hormones, the early embryo and the uterine environment
}

\author{
R. B. Heap, A. P. F. Flint, J. E. Gadsby \\ and Catherine Rice* \\ A.R.C. Institute of Animal Physiology, Babraham, Cambridge CB2 4AT, U.K.
}

Studies using in-vitro culture (Brinster, 1969; Whitten, 1970), in-vitro microsurgery (Gardner, 1968), and embryo transfer to ectopic sites (Fawcett, 1950; Kirby, 1962, 1969) have shown that before blastulation the mammalian ovum develops independently of its uterine environment. After this time the blastocyst becomes less autonomous and development depends increasingly on the local environment. Evidence for dependence upon the uterine milieu also arises from experiments on the transfer of embryos between donor and recipient animals and the transfer of blastocysts to ectopic sites, and from investigations of the phenomenon of delayed implantation. In this paper we consider the nature of the interaction between the endometrium and the blastocyst and indicate where interception may inhibit maternal or embryonic signals which are indispensible for implantation and the establishment of pregnancy.

\section{Influence of the uterine environment on blastocyst development}

Embryonic development proceeds normally only when the uterine environment is adequately prepared to receive a blastocyst of corresponding age. The importance of the similarity in age of an embryo and its uterine environment was first revealed by embryo transfer experiments which indicated that during pregnancy the conditions within the uterus must change progressively, and almost daily, for embryos to show such sensitivity to the environment of the surrogate host. Thus, Chang (1950) working on rabbits demonstrated that embryo transfers succeeded best when the stage of egg development in the donor was synchronized with that of the luteal phase of the recipient, while McLaren \& Michie (1956) found in mice that transfers were most successful if blastocysts were 1 day older than the stage of the uterus in the recipient, less successful in the synchronous combination, and least successful if the relative ages were reversed. In sheep, Rowson \& Moor (1966) showed that eggs either 2 days younger or older than the stage of the recipient uterus exhibited some tolerance to transfer, but this tolerance diminished sharply as the asynchrony became greater. The sensitivity of the blastocyst to its environment was evident also from experiments in which the embryo was confined to the oviduct, since ligation of the uterotubal junction resulted in embryos that developed up to the early blastocyst stage, but no further (mouse: Kirby, 1962; Orsini \& McLaren, 1967; rabbit: Adams, 1958; rat: Alden, 1942; sheep: Winterberger-Torres, 1956; pig: Murray et al., 1971, but see Pope \& Day, 1972). In several of these studies, tube-locked embryos underwent degenerative changes indicating that the tubal environment was detrimental to normal preimplantation development.

Extrinsic control of the growth and development of the mammalian blastocyst has also been studied during delayed implantation. This condition is characterized by a reduction in DNA synthesis and mitosis of cells comprising the blastocyst (McLaren, 1968; Sherman \& Barlow, 1972), and by a decrease in blastocyst metabolism (Menke \& McLaren, 1970) and macromolecular synthesis (Dass, Mohla \& Prasad, 1969; Weitlauf, 1973; Holmes \& Dickson, 1975).

\footnotetext{
* Present address: Harvard Medical School, Laboratory of Human Reproduction and Reproductive Biology, 45 Shattuck Street, Boston, Massachusetts 02115, U.S.A.
} 
Following Brambell's (1937) original suggestion that embryonic diapause resulted either from the production by the uterus of an inhibitory factor or from the lack of an essential stimulatory factor, several attempts have been made to identify these constituents because of their potential importance to understanding the biochemical events associated with the normal process of implantation. However, neither the identity of these factors nor the way in which they control the growth of the blastocyst is known with certainty. Evidence for the involvement of endometrial macromolecules in the regulation of blastocyst metabolism remains speculative (see Surani, 1977), though the finding in rabbits that oestrogen injected shortly after mating delayed both the pattern of uteroglobin secretion and the time of implantation to a similar extent (Beier, 1976) supports the notion that uterine proteins may contribute to the normal process of nidation in certain species. However, the possibility that the concentration of ions and small molecules such as glucose in uterine fluid may be equally important, if not more so, especially in respect of the regulation of blastocyst cell division and metabolism, should not be overlooked (see van Blerkom, Charez \& Bell, 1979).

A co-culture technique has been developed to investigate the nature of endometrial components that influence protein synthesis in the preimplantation blastocyst and to examine whether their production is tissue-specific and time-dependent (Wyatt, 1976). Blastocyst and maternal tissues were removed from pigs immediately after killing on the 16th day of gestation. Although the blastocysts have elongated at this stage, definitive attachment of embryonic and maternal tissues becomes established above $48 \mathrm{~h}$ later, on Day 18 post coitum (p.c.). Blastocysts dissected from the uterus were divided into $5 \mathrm{~mm}$ lengths and maternal explants were prepared as $2 \mathrm{~mm}^{3}$ pieces. The region of the embryonic disc was excluded from these studies, and the tissue was comprised predominantly of trophectoderm. The grid technique was used to culture blastocysts alone or in co-culture with a maternal explant, and protein synthesis was monitored by the incorporation of $\mathrm{L}_{-}\left[4,5-{ }^{3} \mathrm{H}\right]$ leucine. Leucine incorporation into blastocyst tissue proteins and into proteins recovered from the medium was significantly higher when embryonic tissue was cultured together with an endometrial explant $(P<0.01 ; 4$ experiments) than when cultured either alone, or with peritoneum, kidney, liver or striated muscle explants. Disc gel electrophoresis of blastocyst and maternal tissue in $7.5 \%$ polyacrylamide containing $1 \%$ sodium dodecylsulphate, and of spent medium in $7.5 \%$ polyacrylamide, showed that labelled leucine was incorporated into prealbumin protein components in blastocystendometrial co-cultures only. These prealbumin components were first detectable after $8 \mathrm{~h}$ and were present in blastocyst tissue and in the spent medium. Fluid which accumulated within blastocyst tissue in co-culture contained a high concentration of these labelled compounds (Wyatt, Heap \& Perry, 1976). Preliminary studies showed that 16-day blastocyst tissue cocultured with endometrial tissue from the same animal (synchronous) incorporated labelled amino acid to a greater extent than in co-culture with asynchronous tissue; this was partly attributable to the synthesis of proteins with an electrophoretic mobility similar to that of the prealbumin components described above (C. Rice, unpublished observations).

These findings using the pig as an experimental model provide evidence in vitro for endometrial factors that affect protein synthesis in the preimplantation blastocyst. The synthesis of these factors in culture was tissue-specific and their effect on blastocyst protein production was substantially greater than that observed after the addition of equivalent amounts of nonspecific proteins. It is well known that among mammalian species the composition of endometrial secretions is markedly affected by ovarian hormones (see Heap, 1962; Lutwak-Mann, 1971; Renfree, 1978) and that steroid-dependent protein synthesis occurs in uterine tissue (e.g. induced-protein in rat: Barnea \& Gorski, 1970; uteroglobin in rabbit: see Beier, 1976; purple protein in pig: Schlosnagle, Bazer, Tsibris \& Roberts, 1974). In the light of such observations future work will need to establish whether the endometrial factors detected from co-culture studies are essential for blastocyst development in vivo, and whether their production is hormonally dependent, or even induced by the embryo itself. 


\section{Influence of the blastocyst on the uterine environment}

A feature of trophoblast cells is the versatility of their synthetic properties. They produce large amounts of oestrogens as well as progesterone together with a range of glycoproteins (as in woman, sheep and horse), though this capacity is not common to trophoblast tissue in all mammalian species (e.g. rabbit, ferret, dog and cat). Although the placental synthesis of steroid and protein hormones by cells of trophoblastic origin among certain species is well documented, it is only in recent years that the endocrine properties of trophectoderm cells in the preimplantation embryo have been explored directly.

The production of a signal by the developing blastocyst before its attachment to the uterine wall has long been suspected, and such substances may be necessary either for the process of implantation or for the maternal recognition of pregnancy (see Heap et al., 1977; Flint et al., 1979). In women and non-human primates the production of a chorionic gonadotrophin (CG) by trophoblast cells appears to be essential for the sustained secretion of progesterone by the corpus luteum since immunization against the $\beta$-subunit of hCG blocks pregnancy in the marmoset and baboon (Hearn, 1976; Stevens, 1975). However, controversy surrounds the question of the time that hCG is first produced and whether it can be synthesized by the preimplantation blastocyst (see Saxena \& Landesman, 1978). Production of hCG has been reported as early as 6-9 days after fertilization (Saxena, Hasan, Haour \& Schmidt-Gollwitzer, 1974) and in women of known fertility who were fitted with an IUD (Landesman, Coutinho \& Saxena, 1976). However, the latter finding has been disputed (Catt, Dufau \& Vaitukaitis, 1975; Sharpe et al., 1977) and other reports suggest that embryonic cells are not the only source of this glycoprotein (see Ross, 1979).

Whereas hCG comprises an important embryonic signal in women and non-human primates because of its luteotrophic action, in domestic animals such as the sheep, pig and cow the production of an anti-luteolysin by the embryo is essential to neutralize the effect of uterine prostaglandin (PG) F-2 $\alpha$, a luteolysin that probably causes regression of the corpus luteum during the normal cycle. Despite these apparent differences between species in relation to the maintenance of the corpus luteum there may be common embryonic signals that act locally and facilitate the processes of attachment and implantation. In this context the recent demonstrations of steroid synthetic pathways in trophectoderm tissue are noteworthy, particularly in view of the role of oestrogens in the induction of implantation in rodents, and further examination of the evidence is merited.

\section{Oestrogen synthesis by the pig blastocyst}

The pig is a species in which the zona pellucida is lost about Day 6-8 p.c., by Day 10 the blastocyst is about $2 \mathrm{~mm}$ in diameter, by Day 11 it is a spherical or ovoid sac about $5 \mathrm{~mm}$ in diameter, and by Day 14 it has elongated to form a tubular, bilaminar structure of the order of $100 \mathrm{~cm}$ in length. By this time the blastocysts are distributed along the length of the uterine horns and points of loose attachment are formed with the mesometrial surface of the endometrium, but intimate contact between fetal and maternal epithelia by interlocking microvilli is not established until Day 18 (see Perry, Heap, Burton \& Gadsby, 1976). The substantial amounts of embryonic tissue formed before implantation and the non-invasive form of placentation permit the study of embryonic tissue and the immediately adjacent maternal endometrium.

Preimplantation trophectoderm tissue has been found to produce oestrone and oestradiol$17 \beta$ when incubated in vitro with labelled neutral steroid precursors (Perry, Heap \& Amoroso, 1973; Heap, Perry, Gadsby \& Burton, 1975; Perry et al., 1976). Text-figure 1 shows some of the steroid conversions demonstrated in pig blastocyst tissue in vitro including the formation of oestradiol-17 $\beta$ from labelled pregnenolone and progesterone, and of oestrone and oestradiol-17 $\beta$ from labelled dehydroepiandrosterone (DHA) and androstenedione (Gadsby, Burton, Heap \& 


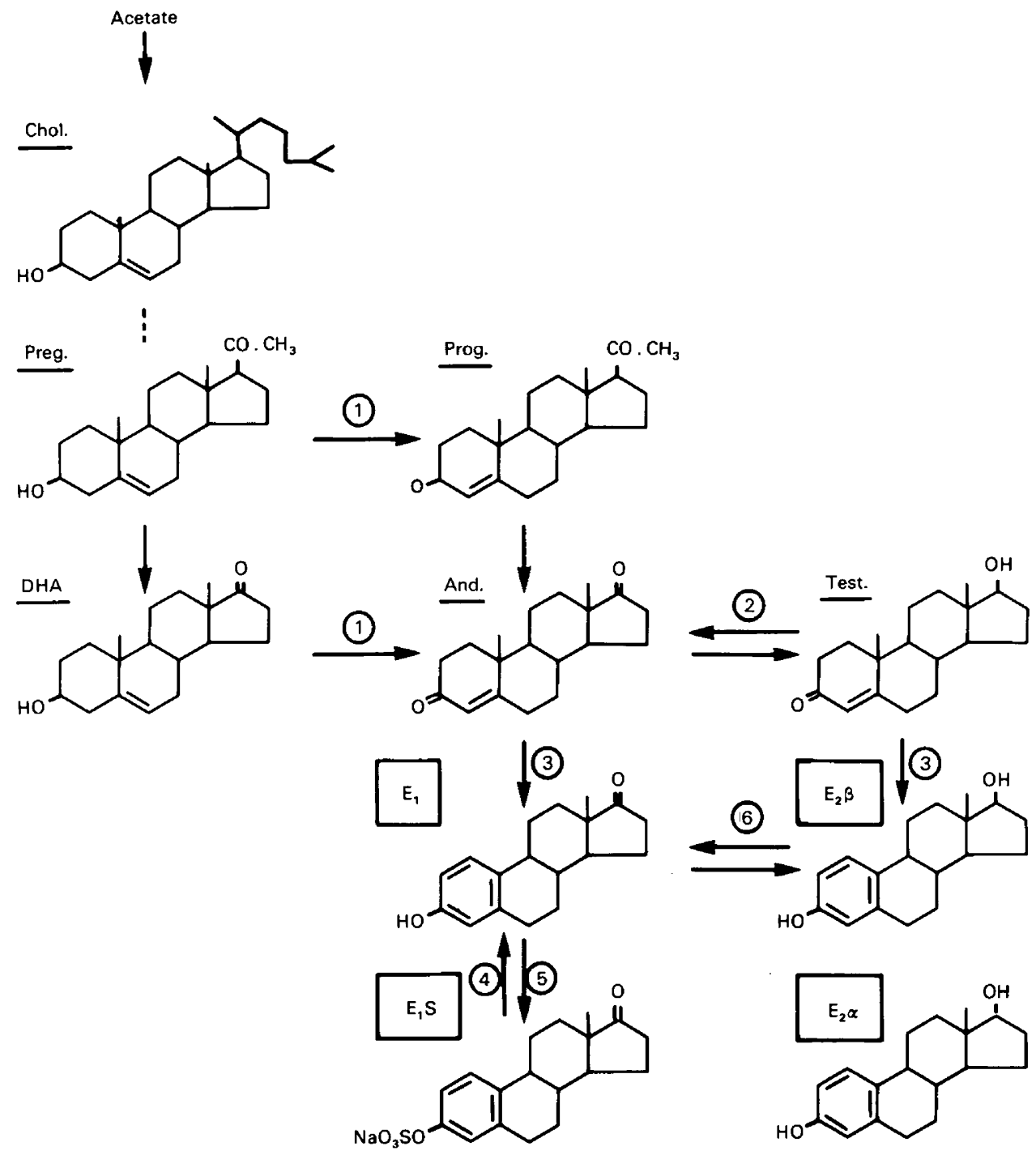

Text-fig. 1. Steroid synthesis in the pig blastocyst. Definitive identification of oestrone $\left(E_{1}\right)$, oestradiol-17 $\beta\left(\mathrm{E}_{2} \beta\right)$, oestradiol-17 $\alpha\left(\mathrm{E}_{2} \alpha\right)$ has been obtained by recrystallization of the products

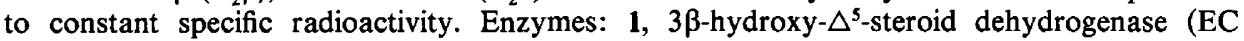
1.1.1.145); 2, testosterone $17 \beta$-dehydrogenase and $17 \beta$-oxidoreductase (EC 1.1.1.63, 1.1.1.64); 3, aromatase; 4, arylsulphatase (EC 3.1.6.1); 5, oestrogen sulphotransferase. Chol., cholesterol; Preg., pregnenolone; Prog., progesterone; DHA, dehydroepiandrosterone; And., androstenedione; Test., testosterone; $E_{1} S$, oestrone sulphate. Dotted line indicates that pathway has not been identified.

Perry, 1976). In addition to the pathways shown in Text-fig. 1 further studies have demonstrated that neutral steroids are rapidly metabolized to other neutral compounds (Gadsby, 1978). The presence of the enzyme, $3 \beta$-hydroxysteroid dehydrogenase ( $3 \beta$-HSD), has been localized in pig blastocyst tissue by histochemical procedures (Flood, 1974). Thus, with the exception of the side-chain cleavage enzyme responsible for the conversion of cholesterol to pregnenolone, the complement of enzymes necessary for the synthesis of oestrogens from acetate appears to be 
present in preimplantation trophectoderm in the pig. Failure to demonstrate the synthesis of pregnenolone in vitro may be related to an endogenous pool of cholesterol which dilutes exogenous labelled sterol and thereby masks any metabolism.

\section{Time of onset of oestrogen synthesis in the pig}

Studies on the time of onset of oestrogen synthesis in the pig blastocyst have been reviewed recently (Heap et al., 1977; Flint et al., 1979). Aromatization is first detectable in vitro on Day 12 p.c., closely related to the time of blastocyst elongation. However, the induction of aromatase seems to precede elongation since oestrogen synthesis has been detected in spherical blastocysts; furthermore, oestrone and oestradiol-17 $\beta$ can be detected by radioimmunoassay in spherical and ovoid blastocysts. In addition to oestrogens substantial concentrations of progesterone have been found in blastocyst tissue at this time arising either from synthesis by trophectoderm cells (see Gadsby \& Heap, 1978) or by uptake from the uterine environment. Progesterone can be utilized by embryonic tissue to produce oestrogens in early pregnancy since labelled oestrone has been identified in fetal membranes after an infusion of $\left[{ }^{3} \mathrm{H}\right]$ progesterone into the uterine artery on Day 22 of gestation (Flint et al., 1979).

A consequence of steroid synthesis in the preimplantation blastocyst is the elevated concentration of oestrone and oestradiol-17 $\beta$ in luminal fluid of the uterine environment. Although these unconjugated oestrogens pass readily into the endometrium, their local tissue concentration is rapidly reduced by sulphotransferase which results in the formation of oestrogen sulphoconjugates with low biological activity. Sulphotransferase activity in the endometrium is related to the secretion of progesterone by the corpus luteum (see Pack \& Brooks, 1974; Perry et al., 1976; Gadsby \& Heap, 1978).

Evidence in vivo and results obtained in vitro show that embryonic tissue acquires the enzymes that convert neutral steroids into oestrogens from Day 12 of gestation. This enzymic capacity appears to be modified as pregnancy progresses; the conversion of $C_{19}$ steroids to oestrogens declines per unit weight of embryonic tissue (Perry et al., 1976); oestrogen concentrations in circulating plasma decline sharply after Day 30 p.c. though they recover subsequently (Robertson \& King, 1974); while in late gestation only $C_{19}$ neutral steroids (and not $C_{21}$ steroids) are converted into oestrogens by placental tissue in vitro (Ainsworth \& Ryan, 1966).

\section{Comparative aspects of blastocyst steroid synthesis}

Considerable evidence for steroid synthesis and metabolism in preimplantation embryonic tissue has accrued from comparative studies in domestic and laboratory animals. Among domestic animals, $\mathrm{C}_{19}$ neutral steroids are extensively metabolized by preimplantation tissue in the sheep and cow. However, in contrast to the pig, the synthesis of oestrogens has been detected only at very low levels of conversion in the cow and is negligible in the sheep (Gadsby et al., 1976; Gadsby, 1978). Among rodents histochemical evidence for steroid synthesis in the preimplantation blastocyst has been published (rat, mouse and hamster; see Dickmann, Dey \& Sen Gupta, 1976), but it is noteworthy that only two enzymes in the synthetic chain of oestrogen production have been demonstrated, and that no histochemical procedure is currently available to detect the presence of the aromatase enzyme. Hitherto, biochemical studies have not confirmed these histochemical observations since preimplantation embryos grown in tissue culture failed to convert $\left[{ }^{3} \mathrm{H}\right]$ pregnenolone to progesterone or $\left[{ }^{3} \mathrm{H}\right] \mathrm{DHA}$ to androstenedione. The enzyme, $3 \beta$-hydroxysteroid dehydrogenase ( $3 \beta$-HSD), demonstrated histochemically by Dickmann and his colleagues in preimplantation embryos was detected biochemically by Sherman and his group in trophoblast outgrowths, but only at a stage that corresponded with post-implantation in vivo (see Sherman, Atienza, Salomon \& Wudl, 1977). 
Definitive evidence for steroid synthesis by blastocysts is difficult to achieve in many species because of the meagre amounts of tissue available. In rabbits, Huff \& Eik-Nes (1966) found that blastocysts produced pregnenolone from labelled acetate in vitro and converted pregnenolone, 17a-hydroxypregnenolone, progesterone and androstenedione into labelled products, including ring-A reduced compounds. These results have been confirmed by Singh \& Booth (1978). Other workers have shown that rabbit blastocysts contain progesterone, progesterone metabolites and oestrogens (Seamark \& Lutwak-Mann, 1972; Dickmann et al., 1975; Borland, Erikson \& Ducibella, 1977), and it is only recently that conclusive proof of blastocyst oestrogen production has been reported for this species. George \& Wilson (1978) have found that androgen (3 $\beta$-HSD activity) and oestrogen formation were detectable on Days 5 and 6 p.c., respectively. The latter activity, as in the pig, declined after implantation. While the suggestion of George \& Wilson (1978) that oestrogen synthesis "can be inferred to be a common property of the blastocyst at the time of implantation" seems premature, it is probable that trophectoderm cells possess the enzymic capacity for steroid synthesis and/or catabolism among several mammals. This idea is further supported by studies of two marsupials, the quokka, Setonix brachyurus, and the tammar wallaby, Macropus eugenii, species in which attachment takes the form of a simple interdigitation between the yolk sac membrane and the endometrial epithelium, and placentation is-non-invasive. In the yolk sac placenta of the quokka there was a small conversion of $\left[{ }^{14} \mathrm{C}\right.$ ]pregnenolone to progesterone (Bradshaw et al., 1975) and in the tammar wallaby $\mathrm{C}_{19}$ neutral steroids were extensively metabolized (Renfree, 1977; M. B. Renfree \& R. B. Heap, unpublished observations).

\section{Physiological role of steroid synthesis by blastocysts}

The ability of many non-endocrine tissues, including skeletal muscle, erythrocytes and fibroblasts, to metabolize steroids has long been recognized, and it is necessary to consider whether related properties exhibited by blastocyst tissue play a physiological role in the events of early gestation. There can be little doubt that in the pig at least blastocysts display the characteristics of an endocrine tissue in that they have the enzymic capacity to synthesize hormonally active steroids (oestrogens); they contain a high concentration of oestradiol-17 $\beta$ and oestrone; after Day 12 p.c. the plasma concentration of oestrogens is progressively higher in the uteroovarian vein than in the peripheral circulation of pregnant but not of non-pregnant animals (Moeljono et al., 1977); and the concentration of conjugated oestrogens formed by the gravid uterus continues to rise to peak values which are reached at about Day 25 p.c. in blood (Robertson \& King, 1974) and in urine (Fèvre, Léglise \& Rombauts, 1968). Blastocyst oestrogen production in the pig is induced at about the time of the maternal recognition of pregnancy and attachment, and in the rabbit it occurs at implantation. The finding that oestrogens are produced for a relatively brief period during implantation in the rabbit suggests that they may exert a functional role. In rabbits and pigs maternal oestrogens of ovarian origin are not essential for implantation to occur, yet oestrogens facilitate implantation and antioestrogens inhibit it in intact and ovariectomized-progesterone-treated does (Bhatt \& Bullock, 1974; Dey, Dickmann \& Sen Gupta, 1976), suggesting that small amounts of these steroids produced locally are advantageous. Although attempts to demonstrate blastocyst oestrogen synthesis in other species have produced inconclusive results, steroid metabolism by preimplantation embryonic tissue has been found consistently in animals studied in detail.

The physiological role of blastocyst oestrogens in the pig has been discussed elsewhere (Heap et al., 1977; Flint et al., 1979). A reduced concentration of PGF-2 $\alpha$ in the utero-ovarian vein of pregnant compared with non-pregnant animals after Day 12 p.c., and the suppression of the uterine release of PGF-2 $\alpha$ by oestrogen administration (Frank, Bazer, Thatcher \& Wilcox, 1977) are findings compatible with the idea that blastocyst oestrogen production neutralizes the 
luteolytic effect of the uterus and thereby plays an important role in the prolongation of the lifespan of the corpus luteum. It has been proposed that the effect of oestrogen is achieved by a redirection of PGF- $2 \alpha$ secretion resulting in an accumulation within the uterine lumen rather than a release into the uterine vein. Among rodents, e.g. as in the rat and mouse, implantation is preceded by an increased capillary permeability in the region of the blastocyst but the identity and source of the factors involved are at present uncertain. However, recent work indicates that prostaglandins may act locally to initiate these characteristic events (Saksena, Lau \& Chang, 1976; Kennedy, 1977; Fenwick et al., 1977). Alternatively, since rabbit blastocysts have been shown to contain prostaglandins on Day 6 p.c. it is possible that they are embryonic in origin and stimulate blastocyst steroid synthesis, the secreted steroids acting locally on the endometrium (Diskmann \& Spilman, 1975).

In summary, recent studies and work in progress draw attention to the versatility of the synthetic capacity of the preimplantation blastocyst exemplified by the production of steroid hormones which may influence locally the secretory properties of the endometrium. Evidence for the production of endometrial components which enhance protein synthesis in trophectoderm tissue emphasizes another aspect of the interaction between the blastocyst and its uterine environment.

We thank Mr R. W. Ash, Mr J. Smith and Mr D. Twiddy for providing animals. J.E.G. acknowledges the support of the Royal College of Veterinary Surgeons Trust Fund and the Meat and Livestock Commission; C.R. received financial support from the World Health Organization.

\section{References}

Adams, C.E. (1958) Egg development in the rabbit: the influence of post-coital ligation of the uterine tube and ovariectomy. J. Endocr. 16, 283-293.

Ainsworth, L. \& Ryan, K.J. (1966) Steroid hormone transformations by endocrine organs from pregnant mammals. I. Estrogen biosynthesis by mammalian placental preparations in vitro. Endocrinology 79 , 875-883.

Alden, R.H. (1942) Aspects of the egg-ovary-oviduct relationship in the albino rat. II. Egg development within the oviduct. J.exp. Zool. 90, 171-177.

Barnea, A. \& Gorski, J. (1970) Estrogen-induced protein. Time course of synthesis. Biochemistry, N.Y. 9, $1899-1904$.

Beier, H.M. (1976) Uteroglobin and related biochemical changes in the reproductive tract during early pregnancy in the rabbit. J. Reprod. Fert., Suppl. 25 , $53-69$.

Bhatt, B.M. \& Bullock, D.W. (1974) Binding of oestradiol to rabbit blastocyst and its possible role in implantation. J. Reprod. Fert. 39. 65-70.

Borland, R.M., Erickson, G.F. \& Ducibella, T. (1977) Accumulation of steroids in rabbit preimplantation blastocysts. J. Reprod. Fert. 49, 219-224.

Bradshaw, S.D., McDonald, I.R., Hähnel, R. \& Heller, H. (1975) Synthesis of progesterone by the placenta of a marsupial. J. Endocr. 65, 451-452.

Brambell, F.W.R. (1937) The influence of lactation on the implantation of the mammalian embryo. Am. J. Obstet. Gynec. 33, 942-953.

Brinster, R.L. (1969) In-vitro cultivation of mammalian ova. Adv. Biosci. 4, 199-233.
Catt, K.J., Dufau, M.L. \& Vaitukaitis, J.L. (1975) Appearance of hCG in pregnancy plasma following the initiation of implantation in the blastocyst. J. clin. Endocr. Metab. 40, 537-540.

Chang, M.C. (1950) Development and fate of transferred rabbit ova or blastocysts in relation to ovulation time of recipients. J. exp. Zool. 114, 197-216.

Dass, C.M., Mohla, S. \& Prasad, M.R. (1969) Time sequence of action of estrogen on nucleic acid and protein synthesis in the uterus and blastocyst during delayed implantation in the rat. Endocrinology 85, $528-536$.

Dey, S.K., Dickmann, Z. \& Sen Gupta, J. (1976) Evidence that the maintenance of early pregnancy in the rabbit requires "blastocyst estrogen". Steroids 28, 481-485.

Dickmann, Z. \& Spilman, C.H. (1975) Prostaglandins in rabbit blastocysts. Science N.Y. 190, 997-998.

Dickmann, Z., Dey, S.K. \& Sen Gupta, J. (1975) Steroidogenesis in rabbit preimplantation embryos. Proc. natn. Acad. Sci. U.S.A. 72, 293-300.

Dickmann, Z., Dey, S.K. \& Sen Gupta, J. (1976) A new concept: control of early pregnancy by steroid hormones originating in the preimplantation embryo. Vitams Horm. 34, 215-242.

Fawcett, D.W. (1950) The development of mouse ova under the kidney capsule. Anat. Rec. 108, 71-91.

Fenwick, L., Jones, R.L., Naylor, B., Poyser, N.L. \& Wilson, N.H. (1977) Production of prostaglandins by the pseudopregnant rat uterus, in vitro, and the effect of tamoxifen with the identification of 6-ketoprostaglandin $\mathrm{F}_{1 \alpha}$ as a major product. $\mathrm{Br} . \mathrm{J}$. Pharmac. 59, $191-199$. 
Fèvre, J., Léglise, P.C. \& Rombauts, P. (1968) Du rôle de l'hypophyse et des ovaires dans la biosynthèse des oestrogènes au cours de la gestation chez la truie. Annls Biol. anim. Biochim. Biophys. 8, 225-233.

Flint, A.P.F., Burton, R.D., Gadsby, J.E., Saunders, P.T.K. \& Heap, R.B. (1979) Blastocyst oestrogen synthesis and the maternal recognition of pregnancy. In Maternal Recognition of Pregnancy. [Ciba Fdn. Colloq. No. 64] Ed. J. Whelan. Elsevier-Excerpta Medica-North Holland, Amsterdam.

Flood, P.F. (1974) Steroid-metabolizing enzymes in the early pig conceptus and in the related endometrium. J. Endocr. 63, 413-414.

Frank, M., Bazer, F.W., Thatcher, W.W. \& Wilcox, C.J. (1977) A study of prostaglandin $F_{2 \alpha}$ as the luteolysin in swine. III. Effects of estradiol valerate on prostaglandin $F$, progestins, estrone and estradiol concentrations in the utero-ovarian vein of nonpregnant gilts. Prostaglandins 14, 1183-1196.

Gadsby, J.E. (1978) Comparative studies of steroid hormones in blastocysts, uterine flushings and endometrium of pig, sheep and cow. In Monographs on Endocrinology. Eds H. M. Beier \& P. Karlson. Springer Verlag, Berlin. (in press).

Gadsby, J.E. \& Heap, R.B. (1978) Steroid hormones and their synthesis in the early embryo. In Novel Aspects of Reproductive Physiology, pp. 263-285. Eds C. H. Spilman \& J. W. Wilks. S.P. Medical and Scientific books, New York.

Gadsby, J.E., Burton, R.D., Heap, R.B. \& Perry, J.S. (1976) Steroid metabolism and synthesis in early embryonic tissue of pig, sheep and cow. J. Endocr. 71, 45-46P.

Gardner, R.L. (1968) Mouse chimaeras obtained by the injection of cells into the blastocyst. Nature, Lond. 220, 596-597.

George, F.W. \& Wilson, J.D. (1978) Estrogen formation in the early rabbit embryo. Science, N.Y. 199, 200 201.

Heap, R.B. (1962) Some chemical constituents of uterine washings: a method of analysis with results from various species. J. Endocr. 24, 367-378.

Heap, R.B., Perry, J.S., Gadsby, J.E. \& Burton, R.D. (1975) Endocrine activities of the blastocyst and early embryonic tissue in the pig. Biochem. Soc. Trans. 3, 1183-1188.

Heap, R.B., Perry, J.S., Burton, R.D., Gadsby, J.E., Wyatt, C. \& Jenkin, G. (1977) Blastocyst steroidogenesis and embryo-maternal interactions in the establishment of pregnancy. In Reproduction and Evolution, pp. 341-347. Eds J. H. Calaby \& C. H. Tyndale-Biscoe. Australian Academy of Science, Canberra.

Hearn, J.P. (1976) Immunization against pregnancy. Proc. R. Soc. Lond. 195, 149-160.

Holmes, P.V. \& Dickson, A.D. (1975) Temporal and spatial aspects of oestrogen-induced RNA, protein and DNA synthesis in delayed implanted mouse blastocysts. J. Anat. 119, 453-459.

Huff, R.L. \& Eik-Nes, K.B. (1966) Metabolism in vitro of acetate and certain steroids by six-day-old rabbit blastocysts. J. Reprod. Fert. 11, 57-63.

Kennedy, T.G. (1977) Evidence for a role for prostaglandins in the initiation of blastocyst implantation in the rat. Biol. Reprod. 16, 286-291.
Kirby, D.R.S. (1962) The influence of the uterine environment on the development of mouse eggs. $J$. Embryol. exp. Morph. 10, 496-506.

Kirby, D.R.S. (1969) The extra-uterine mouse egg as an experimental model. Adv. Biosci. 4, 255-273.

Landesman, R., Coutinho, E.M. \& Saxena, B.B. (1976) Detection of $\mathrm{HCG}$ in blood of regularly bleeding women using $\mathrm{Cu}$ IUCDs. Fert. Steril. 27, 10621066.

Lutwak-Mann, C. (1971) The rabbit blastocyst and its environment: physiological and biochemical aspects. In The Biology of the Blastocyst, pp. 243-261. Ed. R. J. Blandau. University of Chicago Press.

McLaren, A. (1968) A study of blastocysts during delay and subsequent lactation in lactating mice. J. Endocr. 42, 453-463.

McLaren, A. \& Michie, D. (1956) Studies on the transfer of fertilized mouse eggs to uterine foster-mothers. $J$. exp. Biol. 33, 394-416.

Menke, T.M. \& McLaren, A. (1970) Mouse blastocysts grown in vivo and in vitro: carbon dioxide production and trophoblast outgrowth. J. Reprod. Fert. 23, 117-130.

Moeljono, M.P.E., Thatcher, W.W., Bazer, F.W., Frank, M., Owens, L.J. \& Wilcox, C.J. (1977) A study of prostaglandin $F_{2 \alpha}$ as the luteolysin in swine. II. Characterization and comparison of prostaglandin $F$, estrogens and progestin concentrations in uteroovarian vein plasma of non-pregnant and pregnant gilts. Prostaglandins 14, 543-555.

Murray, F.A., Jr., Bazer, F.W., Rundell, J.W., Vincent, C.K., Wallace, H.D. \& Warnick, A.C. (1971) Developmental failure of swine embryos restricted to the oviducal environment. J. Reprod. Fert. 24, 445448.

Orsini, M.W. \& McLaren, A. (1967) Loss of zona pellucida in mice and the effect of tubal ligation and ovariectomy. J. Reprod. Fert. 13, 485-499.

Pack, B.A. \& Brooks, S.C. (1974) Cyclic activity of estrogen sulfotransferase in the gilt uterus. Endocrinology 95, 1680-1690.

Perry, J.S., Heap, R.B. \& Amoroso, E.C. (1973) Steroid hormone production by pig blastocysts. Nature, Lond. 245, 45-47.

Perry, J.S., Heap, R.B., Burton, R.D. \& Gadsby, J.E. (1976) Endocrinology of the blastocyst and its role in the establishment of pregnancy. J. Reprod. Fert., Suppl. 25, 85-104.

Pope, C.E. \& Day, B.N. (1972) The development of pig embryos following restriction to the ampullar portion of the oviduct. J. Reprod. Fert. 31, 135-138.

Renfree, M.B. (1977) Feto-placental influences in marsupial gestation. In Reproduction and Evolution, pp. 325-332. Eds. J. H. Calaby \& C. H. Tyndale-Biscoe. Australian Academy of Science, Canberra.

Renfree, M.B. (1978) Embryonic diapause in mammals-a developmental strategy. In Mechanisms of Dormancy and Developmental Arrest, Ch. 1. Ed. M. E. Clutter. Academic Press, New York.

Robertson, H.A. \& King, G.J. (1974) Plasma concentration of progesterone oestrone and oestradiol-17 $\beta$ and of oestrone sulphate in the pig at implantation, during pregnancy and at parturition. J. Reprod. Fert. 40, $133-141$. 
Ross, G.T. (1979) Human chorionic gonadotrophin and maternal recognition of pregnancy. In Maternal Recognition of Pregnancy. [Ciba Fdn. Colloq. No. 64l Ed. J. Whelan. Elsevier-Excerpta Medica-North Holland, Amsterdam.

Rowson, L.E.A. \& Moor, R.M. (1966) Embryo transfer in the sheep: the significance of synchronizing oestrus in the donor and recipient animal. $J$. Reprod. Fert. 11, 207-212.

Saksena, S.K., Lau, I.F. \& Chang, M.C. (1976) Relationship between oestrogen, prostaglandin $F_{2 \alpha}$ and histamine in delayed implantation in the mouse. Acta endocr., Copenh. 81, 801-807.

Saxena, B.B. \& Landesman, R. (1978) Does implantation occur in the presence of an IUD. Res. Reprod. $10,1-2$.

Saxena, B.B., Hasan, S.H., Haour, F. \& SchmidtGollwitzer, M. (1974) Radioreceptor assay of human chorionic gonadotrophin: detection of early pregnancy. Science, N.Y. 184. 793-795.

Schlosnagle, D.C., Bazer, F.W., Tsibris, J.C.M. \& Roberts, R.M. (1974) An iron-containing phosphatase induced by progesterone in the uterine fluid of pigs. J. biol. Chem. 249, 7574-7579.

Seamark, R.F. \& Lutwak-Mann, C. (1972) Progestins in rabbit blastocysts. J. Reprod. Fert. 29, 147-148.

Sharpe, R.M., Wrixon, W., Hobson, B.M., Corker, C.S., McLean, H.A. \& Short, R.V. (1977) Absence of hCG-like activity in the blood of women fitted with IUCDs. J. clin. Endocr. Metab. 45, 496-499.

Sherman, M.I. \& Barlow, P.W. (1972) Deoxyribonucleic acid content in delayed mouse blastocysts. $J$. Reprod. Fert. 29, 123-126.

Sherman, M.I., Atienza, S.B., Salomon, D.S. \& Wudl, L.R. (1977) Progesterone formation and metabolism by blastocysts and trophoblast cells in vitro. In Development in Mammals, Vol. 2, pp. 209-234. Ed. M. H. Johnson. North-Holland, Amsterdam.
Singh, M.M. \& Booth, W.D. (1978) Studies on the metabolism of neutral steroids by preimplantation rabbit blastocysts in vitro and the origin of blastocyst oestrogen. J. Reprod. Fert. 53, 297-304.

Stevens, V.C. (1975) Antifertility effects from immunization with intact, subunits and fragments of HCG. In Physiological Effects of Immunity Against Reproductive Hormones, pp. 249-274. Eds R. G. Edwards \& M. H. Johnson. Cambridge University Press.

Surani, M.A.H. (1977) Cellular and molecular approaches to blastocyst uterine interactions at implantation. In Development in Mammals, Vol. 1, pp. 245-305. Ed. M. H. Johnson. North-Holland, Amsterdam.

Van Blerkom, J., Charez, D.J. \& Bell, H. (1979) Molecular and cellular aspects of facultative delayed implantation in the mouse. In Maternal Recognition of Pregnancy. [Ciba Fdn. Colloq. No. 64] Ed. J. Whelan. Elsevier-Excerpta Medica-North Holland, Amsterdam.

Weitlauf, H. (1973) Changes in the protein content of blastocysts from normal and delayed implanting mice. Anat. Rec. 176, 121-124.

Whitten, W.K. (1970) Nutrient requirements for the culture of preimplantation embryos in vitro. $A d v$. Biosci. 6, 129-154.

Winterberger-Torres, S. (1956) Les rapports entre l'oeuf en segmentation et la tractus maternel chez la brebis. Proc. 3rd Int. Congr. Anim. Reprod. \& A. I., Cambridge, 1, 62-90.

Wyatt, C. (1976) Endometrial components involved in protein synthesis by 16-day pig blastocyst tissue in culture. J. Physiol., Lond. 260, 73-74P.

Wyatt, C., Heap, R.B. \& Perry, J.S. (1976) Protein synthesis in co-cultures of blastocyst and endometrium explants during blastocyst steroidogenesis in the pig. Proc. Sth Int. Congr. Endocr., Hamburg 266 A. 